\title{
Endometritis in old mares
}

\author{
Elisabeth M. Woodward and Mats H. T. Troedsson \\ The Maxwell H. Gluck Equine Research Center, University of Kentucky, Lexington, USA
}

\begin{abstract}
Summary: A transient uterine inflammation is considered physiological after breeding, and normally subsides within 48 hours in reproductively healthy mares. However, a subset of mares fails to clear the inflammation in a timely fashion and subsequently develop persistent endometritis. The causes and mechanisms of persistent endometritis are multifactorial. In addition to compromised myometrial activity, a defective uterine innate immune response has been attributed to the disease. While persistent endometritis can affect all mares, older mares are particularly at risk, as advanced age has been associated with susceptibility to persistent endometritis. Horses of advanced age undergo an alteration of the immune system including a low-grade, systemic pro-inflammatory response, however a direct correlation with this systemic alteration and susceptibility to persistent endometritis has not yet been investigated. There are multiple treatment strategies available for resolving persistent endometritis, including ecbolics, lavage, antibiotics, immunomodulators, acupuncture, and corrective surgery. While it will never be possible to prevent a mare from ageing, treatments adapted towards the unique needs of the aged mare can improve fertility. Future directions of research into persistent endometritis in the old mare should continue to focus on how ageing affects the reproductive and immune systems.
\end{abstract}

Keywords: endometritis / infertile mare / aged mare / horse / reproduction

Correspondence: Dr. Elisabeth M. Woodward, The Maxwell H. Gluck Equine Research Center, Dept. of Veterinary Science, University of Kentucky, Lexington, KY, 40546-0099, USA, elizabeth.woodward@uky.edu

Citation: Woodward E. M., Troedsson M. H. T. (2014) Endometritis in old mares. Pferdeheilkunde 30, 53-56

\section{Introduction}

Endometritis can be caused by bacteria, spermatozoa, or a combination of both. Consequently, most mares experience multiple transient incidents of endometritis during their lifetime, as the condition is considered physiological after breeding (Troedsson 2006). Regardless of the source of antigenic stimulus, the uterine inflammation subsides within 48 hours in reproductively healthy mares. However, a subset of particularly older mares fails to clear the inflammation in a timely fashion and subsequently develop persistent endometritis.

Advanced age has been associated with susceptibility to persistent endometritis (Ricketts and Alonso 1991, Carnevale and Ginther 1992, Zent and Troedsson 1998, Barbacini et al. 2003). Hughes and Loy observed a disparity in the ability to resolve uterine inflammation between young, fertile mares, and older, sub-fertile mares after an intrauterine challenge using Streptococcus zooepidemicus (Hughes and Loy 1969). In addition, endometrial biopsy score has been correlated to both age and susceptibility to persistent endometritis (Troedsson et al. 1993a, Woodward et al. 2012a).

Internal and external conformation of the reproductive organs have been associated with susceptibility to persistent endometritis (LeBlanc et al. 1994, LeBlanc et al. 1998, Hemberg et al. 2005). These conditions are commonly observed in aged, multiparous mares, and mares in poor body condition.

\section{The mechanism of persistent endometritis}

The innate immune response has been the focus of research for persistent endometritis. Defective uterine polymorhponu- culear leukocytes (PMNs) have been observed in mares susceptible to persistent endometritis (Cheung et al. 1985, Liu et al. 1985, Watson et al. 1987). Later evidience suggested that these deficiencies were due to an alteration in the opsonizing ability of the uterine secretions (Watson et al. 1987, Troedsson et al. 1993b). Further studies demonstrated that delayed uterine clearance in susceptible mares resulted in uterine fluid accumulation and a hostile environment for PMN function (Troedsson and Liu 1991). While delayed uterine clearance has been shown to be associated with impaired myoelectrical activity in response to inflammation (Troedsson et al. 1993a), a relaxation of the uterine ligaments in older mares results in a forward tilted position of the uterus in the abdomen. This may contribute to an inability to physically clear the uterus from inflammation in older mares.

Inflammatory cytokine expression in the endometrium has been implemented in endometritis. There is a delicate balance between the pro and anti-inflammatory responses (Parham 2005, Hackett et al. 2008). Susceptible mares appear to have an alteration in mRNA expression of inflammatory cytokines in response to uterine inflammation compared to the response in resistant mares (Fumuso et al. 2003a, 2006, 2007). In the first hours during the inflammatory response, the alteration appears to be initiated by a deficit in the production of anti-inflammatory cytokines (Christoffersen et al. 2012a, Woodward et al. 2013). These studies suggest that 6 hours after breeding is a critical time for the development of persistent endometritis, although clinical evidence of the disease are not present until much later (>24 hours) (Woodward et al. 2013).

Advanced age has been associated with decreased telomere length and decreased cytokine production in equines (Katepalli et al. 2008). Telomere length shortens with every cell 
division, and over time, cells cease to divide. Additionally, as with humans, equines of advanced age undergo an alteration in the immune system including a low-grade, systemic proinflammatory response (also referred to as "inflammageing") (Adams et al. 2008). An alteration of the immune system in older horses is interesting with regards to declined resistance to persistent endometritis, but a direct correlation with susceptibility has not yet been investigated.

\section{Treatments}

Before treatment strategies are considered, surgical correction of defects in the conformation of the reproductive tract and restoring poor body condition should be performed when needed. Vulvoplasty (the Caslick procedure) (Caslick 1937), is a simple procedure routinely preformed on mares to aid in the prevention of air, fecal debris, and other external contaminants from entering the reproductive tract. Other surgeries such as vaginoplasty (Monin 1972), perineoplasty (Pouret 1982, Trotter and McKinnon 1988), urethroplasty (McKinnon and Belden 1988) and uteropexy (Brink et al. 2010) have also been used to correct anatomical defects which threaten fertility.

There are multiple treatment strategies available for resolving persistent endometritis. These treatments are often used in combination with variations in dose, frequency, duration of treatment, and administration route, and are administered both proactively and reactively (Combs et al. 1996, Watson 2000, Hurtgen 2006, Liu and Troedsson 2008, LeBlanc 2010, Witte et al. 2012) Local or systemic antibiotic therapy is most commonly used in cases with persistent infectious endometritis, and strategies to facilitate uterine clearance through uterotonic therapy or uterine lavage are commonly used in mares with persistent breeding-induced endometritis. While these treatment strategies are effective in most cases, resistance to conventional treatment does occur for various reasons. As a result of this, alternative or complementary treatment strategies have been developed. Some of these have been investigated with regards to mechanism of function and in controlled clinical studies, while the efficacy of other treatments is anecdotal.

The effect of anti-inflammatory treatments has been investigated in mares susceptible to persistent endometritis. Corticosteroids were proposed as an effective proactive treatment strategy for persistent endometritis. Pregnancy rates improved in problem mares treated with 5 doses of predinisolone acetate (Dell'Aqua et al. 2006), and oral administration of $200 \mathrm{mg}$ of prednisolone twice daily for 5 days before breeding (Morris and Eden 2008). Administration of $50 \mathrm{mg}$ of dexamethasone iv at the time of breeding reduced clinical signs of persistent endometritis (Bucca et al. 2008), suggesting that a single dose of $50 \mathrm{mg}$ dexamethasone is both safe and effective for the treatment of persistent endometritis (Bucca et al. 2008). Corticosteroids are known to suppress the expression of pro-inflammatory cytokines in other species and body systems (Hodge et al. 1999, Elenkov 2004). Dexamethasone $(50 \mathrm{mg}$ iv) administered at the time of breeding reduced mRNA expression of IL1B in susceptible mares 6 hours after breeding (Woodward et al. 2012b). After intrauterine infusion with e. coli, dexamethasone reduced IL1B
mRNA expression 3 and 72hours post challenge, and increased expression of the anti-inflammatory cytokines IL6 (which has anti-inflammatory properties in the early stages of inflammation) and IL 103 hours after challenge (Christoffersen et al. 2012b).

Mycobacterial cell wall extract (MCWE) has also been used as a proactive treatment for persistent endometritis, and was found to decrease the number of mares with endometritis after challenge with Streptococcus zooepidemicus (Rogan et al. 2007). Pregnancy rates in mares bred during their foal heat cycle were improved after treatment with MCWE (Fumuso et al. 2003b). In addition, when investigating the uterine inflammatory response to breeding, MCWE was shown to decrease levels of pro-inflammatory cytokines and intrauterine nitric oxide accumulation in susceptible mares (Fumuso et al. 2003a, Fumuso et al. 2007, Woodward et al. 2012b).

Intrauterine infusions of a variety of solutions have been used to treat infectious endometritis. These include iodine, chlorhexidine, hypertonic saline, kerosene, and hydrogen peroxide. Many of these solutions are strong irritants and can cause damage to the endometrium. If povidone iodine is used for intrauterine treatment, it should be used in a very dilute solution (0.05-0.10\%) in LRS. The authors do not recommend routine use of these solutions in the uterus.

A 30\% dimethyl sulfoxide (DMSO) solution or acetylcysteine in a $20 \%$ solution have been added to uterine lavage fluids in mares with suspected biofilms or excessive mucus in the uterus (LeBlanc 2008) N-acetylcysteine (NAC) is a mycolytic agent that has been showed to be safe to use for intrauterine infusions in horses. A $3 \%$ solution $(30 \mathrm{~mL}$ of a $20 \%$ solution NAC to $150 \mathrm{~mL}$ saline) can be infused into the uterus of mares with increased viscosity of uterine secretions. The fluid will be left in the uterus overnight and the uterus will be flushed with LRS the following day. The rationale for these treatments is to break down biofilms or clear mucus by decreasing viscosity from the uterus of mares with persistent infection. Treatments should be carried out together with appropriate antibiotic therapy, and have not yet been evaluated in a controlled study.

EDTA-tris has been shown to be effective in decreasing the visibility of Pseudomonas aeruginosa (Kirkland et al. 1983). EDTA is believed to increase bacteriocidal activity of antibiotics by the binding of $\mathrm{Ca}^{++}$in bacterial cell walls, resulting in increased permeability to antibiotics. Tricide ${ }^{\circledR}$ (Medical Molecular Therapeutics, LLC, Georgia Biobusiness Center, Athens, GA 30602) is commonly used in veterinary practices for this purpose. Daily uterine infusion of $300-500 \mathrm{~mL}$ followed by uterine lavage with LRS within 24 hours has been recommended. Treatments should be combined with or followed by appropriate antibiotic therapy.

Electroacupuncture has been used clinically to increase uterine contractility in mares with delayed uterine clearance. Anecdotal reports are encouraging, and research is needed to confirm the efficacy of this treatment alternative.

Platelet-rich plasma (PRP) and stem cell therapy are two treatment strategies currently used to rebuild damaged tissue in the horse. Most of the research using these strategies is focused on tendon repair; however, equine stem cells were found 
to be incorporated into the endometrium after uterine infusion (Mambelli et al. 2013). It remains to be seen if the cells can reverse endometrial degenerative changes. One report suggests that uterine infusion with PRP reduces post-breeding inflammation (Metcalf et al. 2012). Additional research on the efficacy and mechanism is needed for both treatments.

\section{Conclusion}

While persistent endometritis can affect all mares, older mares are particularly at risk. Several factors associated with age combine to compromise fertility in this subset of mares, and treatments have been developed and customized to address these factors individually. While it will never be possible to prevent a mare from ageing, treatments adapted towards the unique needs of the aged mare can improve fertility. Future directions of research into persistent endometritis in the old mare should continue to focus on how ageing affects the reproductive and immune systems.

\section{References}

Adams A. A., Breathnach C. C., Katepalli M. P., Kohler K. Horohov D. W. (2008) Advanced age in horses affects divisional history of $T$ cells and inflammatory cytokine production. Mech. Ageing Develop. 129, 656-664

Barbacini S., Necchi D., Zavaglia G. Squires E. L. (2003) Retrospective study on the incidence of postinsemination uterine fluid in mares inseminated with frozen/thawed semen. Equine Vet. Sci. 23, 493-496

Brink P., Schumacher J., Schumacher J. (2010) Elevating the uterus (uteropexy) of five mares by laparoscopically imbricating the mesometrium. Equine Vet. J. 42 675-679

Bucca S., Carli A., Buckley T., Dolci G., Fogarty U. (2008) The use of dexamethasone administered to mares at breeding time in the modulation of persistent mating induced endometritis. Theriogenology 70, 1093-1100

Carnevale E. M., Ginther O. J. 1992 Relationships of age to uterine function and reproductive efficiency in mares. Theriogenology 37 $1101-1115$

Caslick E. (1937) The vulva and the vulvo-vaginal orifice and its relation to genital health of the Thoroughbred mare. Cornell Vet. 27, 178-187

Cheung A. T., Liu I. K., Walsh E. M., Miller M. E. (1985) Phagocytic and killing capacities of uterine-derived polymorphonuclear leukocytes from mares resistant and susceptible to chronic endometritis. Am. J. Vet. Res. 46, 1938-1940

Christoffersen M., Woodward E.M., Bojesen A.M., Jacobsen S., Petersen M.R., Troedsson M.H.T., Lehn-Jensen H. (2012a) Inflammatory responses to induced infectious endometritis in mares resistant or susceptible to persistent endometritis. BMC Vet. Res. 8, 41

Christoffersen M., Woodward E. M., Bojesen A. M., Petersen M. R., Squires E. L., Lehn-Jensen H., Troedsson M. H. T. (2012b) Effect of immunomodulatory therapy on the endometrial inflammatory response to induced infectious endometritis in susceptible mares. Theriogenology 78, 991-1004

Combs G.B. , LeBlanc M. M., Neuwirth L., Tran T. Q. (1996) Effects of prostaglandin F2, cloprostenol and fenprostalene on uterine clearance of radiocolloid in the mare. Theriogenology 45, 1449-1455

Dell'Aqua J. A., Papa F. O., Lopes M. D., Alvarenga M. A., Macedo L. P., Melo C. M. (2006) Modulation of acute uterine inflammatory response after artificial insemination with equine frozen semen. Anim. Reprod. Sci. 94, 270-273

Elenkov I. J. (2004) Glucocorticoids and the Th1/Th2 balance. Annual. NY Academy of Science 1024, 138-146
Fumuso E., Giguere S., Wade J., Rogan D., Videla-Dorna I., Bowden R. A. (2003a) Endometrial IL-1 beta, IL-6 and TNF-alpha, mRNA expression in mares resistant or susceptible to post-breeding endometritis. Effects of estrous cycle, artificial insemination and immunomodulation. Vet. Immunol. Immunopathol. 96, 31-41

Fumuso E., Alvarez G., Bruno S., Videla-Dorna I., Wade J., Rogan D., Bowden R. A. (2003b). Non-specific immunomodulation at post-partum improves uterine condition and fertility in mares. In: 8th World Equine Veterinary Association.

Fumuso E., Aguilar G., Giguere S., David O., Wade J., Rogan D. (2006) Interleukin-8 (IL-8) and 10 (IL-10) mRNA transcriptions in the endometrium of normal mares and mares susceptible to persistent post-breeding endometritis. Anim. Reprod. Sci. 94, 282-285

Fumuso E., Aguilar J., Giguere S., Rivulgo M., Wade J., Rogan D. (2007) Immune parameters in mares resistant and susceptible to persistent post-breeding endometritis: effects of immunomodulation. Vet. Immunol. Immunopathol. 118, 30-39

Hackett T. L., Holloway R., Holgate S. T., Warner J. A. (2008) Dynamics of pro-inflammatory and anti-inflammatory cytokine release during acute inflammation in chronic obstructive pulmonary disease: an ex vivo study. Respir. Res. 9, 47

Hemberg E., Lundeheim N., Einarsson S. (2005) Retrospective study on vulvar conformation in relation to endometrial cytology and fertility in thoroughbred mares. Vet. Med. A Physiol. Pathol. Clin. Med. 52, 474-477

Hodge S., Hodge G., Flower R., Han P. (1999) Methyl-prednisolone up-regulates monocyte interleukin-10 production in stimulated whole blood. Scand. J. Immunol. 49, 548-553

Hughes J, Loy R. (1969). Investigations on the effect of intrauterine inoculations of streptococcus zooepidemicus in the mare. In: 15th Annual Conference of the American Association of Equine Practitioners

Hurtgen J. P. (2006) Pathogenesis and treatment of endometritis in the mare: a review. Theriogenology 66, 560-566

Katepalli M. P,. Adams A. A., Lear T. L., Horohov D. W. (2008) The effect of age and telomere length on immune function in the horse. Develop. Comp. Immunol. 32, 1409-1415

Kirkland K. D., Fales W. H., Blanchard T. L., Youngquist R. S., Hurtgen J. P. (1983) The in vitro effects of EDTA-tris, EDTA-tris-lysozyme, and antimicrobial agents on equine genital isolants of Pseudomonas aeruginosa. Theriogenology 20, 287-295

Morris L., Eden C.(2008) The use of corticosteroids at the time of mating to prevent post breeding endometritis. Austral. College Vet. Scient. 88-89

LeBlanc M. M. (2008) The chronically infertile mare. In: 54th Annual Convention of the American Association of Equine Practitoners $391-407$

LeBlanc M. M. (2010) Advances in the diagnosis and treatment of chronic infectious and post-mating-induced endometritis in the mare. Reprod. Dom. Anim. 45 Suppl 2, 21-27

LeBlanc M. M., Neuwirth L., Asbury A. C., Tran T., Mauragis D., Klapstein E. (1994) Scintigraphic measurement of uterine clearance in normal mares and mares with recurrent endometritis. Equine Vet. J. 26 109-113

LeBlanc M. M., Neuwirth L., Jones L., Cage C., Mauragis D. (1998) Differences in uterine position of reproductively normal mares and those with delayed uterine clearance detected by scintigraphy. Theriogenology 50, 49-54

Liu I. K., Cheung A. T., Walsh E. M., Miller M. E., Lindenberg P. M. (1985) Comparison of peripheral blood and uterine-derived polymorphonuclear leukocytes from mares resistant and susceptible to chronic endometritis: chemotactic and cell elastimetry analysis. Am. J. Vet. Res. 46, 917-920

Liv I. K., Troedsson M. H. T. (2008) The diagnosis and treatment of endometritis in the mare: yesterday and today. Theriogenology 70 , 415-420

Mambelli L. I., Winter G. H., Kerkis A., Malschitzky E., Mattos R. C., Kerkis I. (2013) A novel strategy of mesenchymal stem cells delivery in the uterus of mares with endometrosis. Theriogenology 79 , 744-750 
McKinnon A. O., Belden J. O. (1988) A urethral extension technique to correct urine pooling (vesicovaginal reflux) in mares. J. Am. Vet. Med. Assoc. 192, 647-650

Metcalf E. S., Scoggin K., Troedsson M. H. T. (2012) The effect of platelet-rich plasma on endometrial pro-inflammatory cytokines in susceptible mares following semen deposition. Equine Vet. Sci. 32. 498

Parham P (2005) The Immune System. New York, NY: Garland Science

Pouret E. J. (1982) Surgical technique for the correction of pneumoand arovagina. Equine Vet. J. 14, 249-250

Ricketts S. W., Alonso S. (1991) The effect of age and parity on the development of equine chronic endometrial disease. Equine Vet. J. 23, 189-192

Rogan D., Fumuso E., Rodríguez E., Wade J., Sánchez Bruni S. F. (2007) Use of a Mycobacterial Cell Wall Extract (MCWE) in Susceptible Mares to Clear Experimentally Induced Endometritis With Streptococcus zooepidemicus. Equine Vet. Sci. 27, 112-117

Monin T (1972) Vaginoplasty: A surgical treatment for urine pooling in the mare. In: 18th American Association of Equine Practitioners 99-192

Troedsson M. H. T. (2006) Breeding-induced endometritis in mares. Vet. Clin. North Am. Equine Pract. 22, 705-712

Troedsson M. H. T., Liv I. K. (1991) Uterine clearance of non-antigenic markers $(51 \mathrm{Cr})$ in response to a bacterial challenge in mares potentially susceptible and resistant to chronic uterine infections. Reprod Fertil Suppl 44, 283-288

Troedsson M. H. T., Liu I. K., Ing M. Pascoe J., Thurmond M. (1993a) Multiple site electromyography recordings of uterine activity following an intrauterine bacterial challenge in mares susceptible and resistant to chronic uterine infection. Reprod Fertil 99, 307-313

Troedsson M. H., Liv I. K., Thurmond M. (1993b) Function of uterine and blood-derived polymorphonuclear neutrophils in mares susceptible and resistant to chronic uterine infection: phagocytosis and chemotaxis. Biol. Reprod. 49, 507-514

Trotter G. W., McKinnon A. O. (1988) Surgery for abnormal vulvar and perineal conformation in the mare. Vet. Clin. North Am. Equine Pract. 4, 389-405

Zent W., Troedsson M. H. T. (1998) Postbreeding uterine fluid accumulation in a normal population of Thoroughbred mares: a field study. In: 44th Annual Convention of the American Association of Equine Practitioners

Watson E. D. (2000) Post-breeding endometritis in the mare. Anim. Reprod. Sci. 60-61, 221-232

Watson E. D., Stokes C. R., Bourne F. J. (1987) Cellular and humoral defence mechanisms in mares susceptible and resistant to persistent endometritis. Vet. Immunol. Immunopathol. 16, 107-121

Witte T. S., Melkus E., Walter I., Senge B., Schwab S., Aurich C., Heuwieser W. (2012) Effects of oral treatment with N-acetylcysteine on the viscosity of intrauterine mucus and endometrial function in estrous mares. Theriogenology 78, $1199-1208$
Woodward E. M., Christoffersen M., Campos J., Squires E. L., Troedsson M. H. T. (2012a) Susceptibility to persistent breedinginduced endometritis in the mare: relationship to endometrial biopsy score and age, and variations between seasons. Theriogenology 78, 495-501

Woodward E. M., Christoffersen M., Horohov D., Squires E. L., Troedsson M. H. T. (2012b) The effect of immune modulators on endometrial cytokine expression in mares susceptible to persistent breeding induced endometritis. In: 17th International Congress on Animal Reproduction.

Woodward E. M., Christoffersen M., Campos J., Betancourt A., Horohov D., Scoggin K. E., Squires E. L., Troedsson M. H.T. (2013) Endometrial inflammatory markers of the early immune response in mares susceptible or resistant to persistent breedinginduced endometritis. Reproduction 145, 289-296

\section{Endometritis bei alten Stuten}

Eine transiente Endometritis nach Bedeckung oder Besamung gilt als physiologisch und klingt bei gynäkologisch gesunden Stuten in der Regel innerhalb von 48 Stunden ab. Allerdings gelingt es einem Teil der Stuten nicht, den Entzündungsprozess in adäquater Zeit zu beenden, sie entwickeln eine persistierende Endometritis. Die Ursachen und Mechanismen der persistierenden Endometritis sind multifaktoriell. Neben einer beeinträchtigten myometrialen Aktivität wird eine defekte angeborene uterine Immunantwort für diese Erkrankung verantwortlich gemacht. Die persistierende Endometritis kann alle Stuten betreffen, besonders gefährdet sind jedoch ältere Stuten, da ein fortgeschrittenes Alter mit einer Anfälligkeit gegenüber einer persistierenden Endometritis in Zusammenhang gebracht wird. Alternde Pferde durchlaufen eine Veränderung des Immunsystems mit einer reduzierten systemischen pro-inflammatorischen Antwort. Eine direkte Korrelation zwischen dieser systemischen Alteration und der Anfälligkeit für eine persistierende Endometritis wurde jedoch noch nicht untersucht. Es stehen mehrere Strategien zur Behandlung der persistierenden Endometritis zur Verfügung, einschließlich myometrialer Stimulantien, Spülungen, Antibiotika, Immunmodulatoren, Akupunktur und korrigierende chirurgische Eingriffe. Während es nie möglich sein wird, dass Altern einer Stute per se zu verhindern, können Behandlungen, die an die individuellen Bedürfnisse einer alternden Stute angepasst sind, die Fruchtbarkeit verbessern. Künftige Forschungen bezüglich der persistierenden Endometritis sollten folgen, um zu klären, inwieweit sich das Altern auf das Fortpflanzungs- und Immunsystem auswirkt.

Schlüsselwörter: Endometritis / infertile Stute / alte Stute / Reproduktion 